\title{
Suplementasi Keong Mas (Pomacea canaliculata Lamarck) dalam Ransum Berbasis Limbah Restoran dan Ampas Kelapa terhadap Performa Itik Hibrida
}

D M Suci', R Mareta', N Y Hidayatulloh', W Hermana'

Corresponding email:
dwi.margi2@gmail.com

'Department of Animal Nutrition and Feed Technology, Faculty of Animal Science, IPB University (Bogor Agricultural University)

\section{ABSTRACT}

This research was aimed to evaluate the effect of boiled golden snail (Pomacea canaliculata Lamarck) supplementation on duck diet based on restaurant waste and coconut pulp to duck performance. A total of 80 Mojosari-Peking hybrid ducks 23 days old were reared for 40 days in this study. The treatments diet was as follows: control diet and 3 treatments diet of boiled golden snail supplementation levels of $10 \%, 15 \%$ and $20 \%$. This research used a completely randomized design with 4 treatments and 4 replicates. All data was analyzed by variance and if there were significantly differences, further analysis applied was a Duncan Multiple Range Test. The variables observed were duck performance (feed consumption, body weight gain and feed conversion ratio) and carcass percentage. The results showed that supplementation of boiled golden snail on diet based on restaurant waste and coconut pulp 10\%-20\% significantly $(\mathrm{p}<0.05)$ increased body weight gain, final body weight, percentage of carcass but decreased feed conversion ratio. It can be concluded that $15 \%$ of boiled golden snail (Pomacea canilaculata Lamarck) supplementation on diet based on restaurant waste and coconut pulp can be use as diet of Mojosari-Peking Hybrid duck.

Keywords: carcass, hybrid duck, performance, Pomacea canilaculata

\section{ABSTRAK}

Tujuan dari penelitian ini adalah mengetahui pengaruh suplementasi keong mas rebus pada ransum berbasis limbah restoran dan ampas kelapa terhadap performa dan persentase karkas itik hibrida Mojosari-Peking (MP). Penelitian ini menggunakan 80 ekor itik MP hibrida (Mojosari-Peking) periode grower umur 23 hari dengan bobot badan $529,18 \pm 81$ g yang dipelihara selama 40 hari. Perlakuan terdiri dari kontrol (tanpa suplementasi keong mas) dan 3 level penambahan keong mas: 10\%, 15\%, dan 20\%. Penelitian ini menggunakan Rancangan Acak Lengkap dengan 4 perlakuan dan 4 ulangan. Data dianalisis Sidik Ragam, bila terdapat perbedaan nyata dilakukan Uji Duncan Multiple Range Test. Peubah yang diamati adalah performa (konsumsi ransum, pertambahan bobot badan dan konversi ransum) dan persentase karkas. Hasil penelitian menunjukkan bahwa suplementasi keong mas dalam ransum dapat meningkatkan pertambahan bobot badan, bobot badan akhir dan persentase karkas tetapi menurunkan konversi ransum. Simpulan hasil penelitian menunjukkan bahwa level 15\% suplementasi keong mas dalam ransum berbasis limbah restoran dan ampas kelapa menghasilkan performa terbaik.

Kata kunci: itik hibrida, karkas, organ dalam, performa, Pomacea canaliculata 


\section{PENDAHULUAN}

Ransum merupakan biaya terbesar dari usaha peternakan itik. Efisiensi ransum yang tinggi merupakan tujuan utama untuk mendapatkan keuntungan. Itik Mojosari-Peking (MP) merupakan itik persilangan dari 2 jenis itik lokal yang dipelihara untuk produksi daging. Pada peternaan itik hibrida banyak menggunakan ransum yang murah agar dapat menekan biaya ransum. Ransum yang murah dapat menggunakan bahan pakan lokal seperti limbah restoran, ampas kelapa dan keong mas (Pomacea canilaculata).

Limbah restoran dapat digunakan sebagai campuran ransum ayam unggas. Kandungan nutrien limbah restoran tergantung dari komponen makanan yang ada di limbah restoran. Limbah restoran yang ada di DKI mengandung rata-rata protein 10,89\%; kalsium 10,89\%; posfor 0,08\%; serat kasar 0,39\%; lemak kasar 9,13\% dan energi metabolis $1.780 \mathrm{kkal} / \mathrm{kg}$ (Muflihani et al. 2000. Pemberian limbah restoran pada ayam dapat mencapai $75 \%$ yang dicampur dengan ransum komersial (Muflihani et al. 2000). Penggunaan limbah restoran dalam ransum dapat menekan biaya produksi 23,42\% sampai dengan 35,13\%, sehingga dapat meningkatkan pendapatan peternak (Muflihani etal. 2000).

Ampas kelapa merupakan limbah dari pengolahan santan kelapa yang masih mempunyai nutrien yang dapat dimanfaatkan oleh ternak. Ampas kelapa mengandung protein kasar 5,38\%; lemak 53,49 \%; serat kasar 7,24\%; BETN 32,90\% pada bahan kering 32,49\% (Kurniawan et al. 2016) sedangkan Ramdani et al.(2016) menyatakan tepung ampas kelapa (BK 87,1\%) mengandung protein $3,95 \%$, lemak 26,19\%, serat kasar $12,92 \%$ dan abu $1,61 \%$. Penggunaan tepung ampas kelapa pada ayam kampung dapat mencapai $40 \%$ tidak mempengaruhi persentase karkas ayam kampung (Ramdani et al. 2016). Potensi ampas kelapa banyak ditemukan di pasar tradisional yang menyediakan jasa pengolahan santan.

Ransum yang terdiri dari limbah restoran dan ampas kelapa mengandung nutrien yang rendah terutama kadar proteinnya. Penambahan bahan pakan sumber protein dapat meningkatkan keseimbangan nutrien ransum sehingga dapat memperbaiki performa itik. Bahan pakan alternatif yang dapat menambah protein ransum berbasis limbah restoran dan ampas kelapa adalah keong mas. Keong mas berpotensi sebagai sumber protein unggas karena terdapat banyak di saluran air (parit), tepi sungai, sawah dan padang rumput (Subhan 2016). Keong mas mempunyai nutrien yang cukup sebagai bahan pakan (Nafiu \& Pagala 2010; Sundari 2004) dan dapat digunakan sampai $20 \%$ pada itik Mojosari-Alabio (Budiari et al. 2016) Tujuan penelitian untuk mengevaluasi pengaruh penambahan keong mas rebus terhadap performa itik hibrida Mojosari-Peking yang diberi ransum berbasis limbah restoran dan ampas kelapa.

\section{METODE}

\section{Kandang, Ternak dan Ransum}

Kandang yang digunakan sebanyak 16 petak terbuat dari bambu yang dilengkapi dengan tempat ransum dan tempat air minum, serta lampu sebagai alat penerangan. Itik hibrida Mojosari-Peking (MP) yang digunakan sebanyak 80 ekor berumur 23 hari (periode grower) dengan bobot badan berkisar 529,18 $\pm 81 \mathrm{~g}$. Ransum yang diberikan terdiri atas campuran limbah restoran dan ampas kelapa dengan perbandingan 1:2. Keong mas yang digunakan direbus lebih dahulu selama 15 menit, kemudian dipecah dan dicampur ke dalam ransum limbah restoran-ampas kelapa (cangkang dan daging). Ransum yang diberikan dalam bentuk basah.

\section{Pemeliharaan}

Pemeliharaan itik dilakukan selama 40 hari. Pemberian ransum dan air minum dilakukan 2 kali sehari yaitu pagi hari dan sore hari. Keong mas rebus dicampurkan dengan limbah restoran dan ampas kelapa dalam bentuk basah dengan jumlah sesuai dengan perlakuan. Penimbangan bobot badan dilakukan pada saatitik berumur 23 hari dan 63 hari. Penimbangan ransum yang dikonsumsi dilakukan setiap hari. Tempat ransum dan air minum dibersihkan setiap hari. Jumlah ransum yang diberikan ke itik sebesar 333,2 g ekor- ${ }^{1}$ hari $^{-1}$ pada minggu pertama. Penambahan sebanyak $50 \mathrm{~g}$ ekor- ${ }^{1}$ hari $^{-1}$ dilakukan pada minggu ke dua hingga minggu ke tiga. Pada minggu ke empat sampai minggu ke enam ransum ditambah $100 \mathrm{~g}$ ekor $^{-1}$ hari $^{-1}$.

\section{Pemotongan Itik}

Itik dipotong sebanyak 24 ekor pada umur 63 hari untuk mendapatkan bobot karkas, lemak abdominal dan bobot organ dalam. Karkas yaitu itik yang telah dipotong, dibului, dipotong kepala, leher dan kaki serta telah dikeluarkan organ dalam dan saluran pencernaan. Lemak abdominal adalah lemak yang berada pada abdomen perut. Persentase karkas atau lemak abdominal dihitung dengan membagi bobot karkas atau bobot lemak abdominal dengan bobot potong. Persentase organ dalam dihitung dengan membagi bobot organ dalam dengan bobot karkas.

\section{Rancangan Penelitian dan Analisis Data}

Rancangan Acak Lengkap dengan 4 perlakuan dan 4 ulangan, setiap ulangan terdiri atas 5 ekor itik. Perlakuan yang digunakan dalam penelitian ini adalah ransum kontrol (tanpa penambahan keong mas dalam ransum) dan ransum dengan suplementasi keong mas rebus sebanyak $10 \%$, 15\% dan 20\% dari pemberian jumlah limbah restoran dan ampas kelapa.

Data yang diperoleh dianalisis sidik ragam, bila terdapat perbedaan nyata dilanjutkan dengan Uji Duncan Multiple Range Test. Peubah yang diamati konsumsi ransum, bobot badan, konversi ransum, bobot karkas, lemak abdomen dan bobot organ dalam. Konsumsi ransum diukur dengan mengurangi jumlah pemberian 
Tabel 1 Kandungan nutrien bahan pakan itik yang digunakan pada penelitian

\begin{tabular}{|c|c|c|c|c|c|c|}
\hline \multirow{2}{*}{ Bahan Pakan } & Kadar Air & Abu & Protein Kasar & Lemak Kasar & Serat Kasar & BETN \\
\hline & \multicolumn{6}{|c|}{ 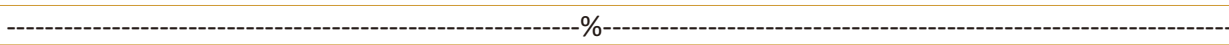 } \\
\hline Ampas kelapa & 69,79 & 0,48 & 2,05 & 11,10 & 8,69 & 7,89 \\
\hline Limbah restoran & 80,36 & 1,72 & 4,67 & 1,66 & 0,85 & 10,7 \\
\hline Keong mas rebus & 52,94 & 32,17 & 7,07 & 0,43 & 0,08 & 7,31 \\
\hline
\end{tabular}

Hasil analisis Laboratorium Pusat Penelitian Sumberdaya Hayati dan Bioteknologi PAU (Pusat Antar Universitas) Institut Pertanian Bogor

ransum dan sisa ransum. Konversi ransum dihitung dengan membagi konsumsi ransum per pertambahan bobot badan. Pertambahan bobot badan adalah selisih bobot badan akhir dengan bobot badan awal.

\section{HASIL DAN PEMBAHASAN}

\section{Karakteristik Limbah Restoran, Ampas Kelapa, Keong Mas}

Ransum yang digunakan adalah campuran limbah restoran dengan ampas kelapa serta keong mas yang telah direbus dan dihancurkan. Pemanfaatan limbah restoran ini merupakan alternatif untuk mengurangi biaya ransum. Limbah restoran diperoleh dari hotel dan ampas kelapa diperoleh dari pasar tradisional .

Limbah restoran yang digunakan dalam penelitian mempunyai komposisi bahan makanan yaitu nasi $69 \%$, sayuran $15 \%$, buah $4 \%$ dan daging $12 \%$. Limbah restoran dan ampas kelapa pada kondisi basah (Tabel 1). Ampas kelapa merupakan hasil ikutan pembuatan santan kelapa. Ampas kelapa hasil samping pembuatan minyak kelapa murni masih memiliki kandungan protein yang cukup tinggi. Hal ini menyebabkan ampas kelapa berpotensi untuk dimanfaatkan sebagai bahan campuran ransum (Miskiyah 2006). Selain itu ampas kelapa mempunyai kadar serat kasar dan lemak kasar yang cukup tinggi (Tabel 1).

Keong mas yang digunakan mempunyai ukuran yang tidak sama rata-rata dengan berat sekitar 5-30 g ekor ${ }^{-1}$. Keong mas direbus selama 15-20 menit, kemudian dipecah dan dicampur ke dalam ransum itik. Keong mas yang digunakan pada penelitian ini bersama cangkangnya sehingga kadar abu sangat tinggi. Persentase daging yang dihasilkan dari setiap ekor keong mas beragam tergantung dari bobot total per ekornya. Berdasarkan pengamatan bobot daging keong mas sinergis dengan besarnya keong. Keong yang diberikan dalam bentuk segar dengan kadar air $52,94 \%$, bila dipisahkan daging dan cangkangnya masing-masing mempunyai kadar air $76,7 \%$ dan $19,42 \%$. Ransum

Tabel 2 Kandungan nutrien ransum penelitian

\begin{tabular}{|c|c|c|c|c|}
\hline \multirow[b]{2}{*}{ Komposisi } & \multicolumn{4}{|c|}{ Suplementasi Keong Mas Rebus (\%) } \\
\hline & 0 & 10 & 15 & 20 \\
\hline $\begin{array}{l}\text { Kadar Air Ransum } \\
\text { Kandungan nutrien* }\end{array}$ & $73 \%$ & & & \\
\hline Protein Kasar & 2,92 & 3,32 & 3,53 & 3,73 \\
\hline Lemak Kasar & 7,95 & 7,97 & 7,98 & 7,98 \\
\hline Serat Kasar & 6,07 & 6,07 & 6,08 & 6,08 \\
\hline Bahan Ekstrak Tanpa N & 9,17 & 6,91 & 5,75 & 4,63 \\
\hline Abu & 0,89 & 2,73 & 3,66 & 4,58 \\
\hline
\end{tabular}

Hasil analisis Laboratorium Pusat Penelitian Sumberdaya Hayati dan Bioteknologi PAU (Pusat Antar Universitas) Institut Pertanian Bogor berbasis limbah restoran dan ampas kelapa mempunyai kadar air $73 \%$ dengan kandungan protein kasar 2,92 \% (Tabel2).

\section{Performa Itik Hibrida yang Disuplemen dengan Keong Mas Rebus}

Penambahan keong emas dari 10\%, 15\% dan 20\% akan meningkatkan protein sebesar $0,07 \%$ sampai $1,06 \%$, selain itu terdapat penambahan nutrien lainnya seperti asam amino dan mineral (terutama Ca dan P). Daging keong mas mengandung metionin 3,48\% dan lisin 4,18\% (Kaensombath 2016). Peningkatan protein ransum yang rendah karena keong mas diberikan dalam bentuk segar, apabila keong mas dikeringkan maka terdapat penambahan protein yang tinggi. Performa itik hibrida yang disuplementasi keong mas rebus terdapat pada Tabel 3.

Suplementasi $10 \%$ dan 15\% keong mas rebus dalam ransum itik menunjukkan pertambahan bobotbadan dan bobot badan akhir itik (umur 63 hari) nyata $(p<0,05)$ lebih tinggi dibandingkan ransum kontrol tetapi suplementasi $20 \%$ keong mas menunjukkan kecenderungan menurunkan pertambahan bobot badan dan bobot badan akhir itik (Tabel 3). Pertambahan bobot badan yang nyata meningkat diperoleh pada konsumsi ransum yang sama, hal ini menujukkan adanya peningkatan efisiensi pencernaan dan penyerapan nutrien pada ransum yang disuplementasi keong mas rebus $10-15 \%$, ditunjang oleh data konversi ransum yang semakin rendah bila dibandingkan dengan kontrol (2,6 vs 3,5 ). Peningkatan pertambahan bobot badan itik yang tidak terlalu tinggi dengan suplementasi keong mas rebus disebabkan oleh pemberiannya dalam bentuk segar, sehingga jumlah peningkatan nutrien tidak terlalu nyata. Jika suplementasi keong mas dalam bentuk tepung maka akan terjadi peningkatan jumlah nutrien yang tinggi di dalam ransum. Bombeo-Tuburan et al. (1995) menyatakan daging keong mas mengandung protein 54\% (\% bahan kering), asam amino esensial yang dominan leusin dan lisin dan proporsi asam lemak tidak jenuh $60,5 \%$ sedangkan asam lemak jenuh $39,5 \%$.

Penurunan pertambahan bobot badan pada suplementasi keong mas $20 \%$ disebabkan oleh faktor lain karena kecernaan protein daging keong mas yaitu 86,36 $\%$, jika dibandingkan dengan tepung ikan $88,69 \%$ (Jintasataporn \& Yenmark 2004). Beberapa faktor yang diduga dapat menurunkan kecernaan ransum yang disuplementasi keong mas adalah kandungan abu yang tinggi bila pemberian dengan cangkangnya dan adanya jenis protein daging keong mas yang sulit dicerna (Hertrampf \& Piedad-Pascual 2000). Penggunaan tepung keong dapat meningkatkan performa apabila ditambah 
Tabel 3 Rataan performa Itik Mojosari-Peking dari umur 23 hari - 63 hari

\begin{tabular}{|c|c|c|c|c|}
\hline \multirow{2}{*}{ Peubah } & \multicolumn{4}{|c|}{ Suplementasi Keong Mas Rebus (\%) } \\
\hline & 0 & 10 & 15 & 20 \\
\hline Pertambahan bobot badan (g ekor ${ }^{-1}$ ) & $645,15 \pm 59,45^{c}$ & $868,62 \pm 25,87^{a}$ & $840,40 \pm 54,60^{a b}$ & $733,92 \pm 127,03^{\mathrm{bc}}$ \\
\hline Bobot badan akhir (g ekor ${ }^{-1}$ ) & $1165,56 \pm 56,41^{b}$ & $1415,55 \pm 57,23^{\mathrm{a}}$ & $1389,7 \pm 97,86^{\mathrm{a}}$ & $1234,05 \pm 158,13^{\mathrm{ab}}$ \\
\hline Konsumsi ransum basah $(73 \% \mathrm{KA})\left(\mathrm{g}\right.$ ekor $\left.{ }^{-1}\right)$ & $14897,15 \pm 89,21$ & $4936,38 \pm 84,91$ & $4861,55 \pm 224,41$ & $4883,73 \pm 89,4$ \\
\hline Konversi ransum basah (KA73\%) & $22,62 \pm 2,13^{b}$ & $16,76 \pm 0,44^{\mathrm{a}}$ & $17,27 \pm 1,10^{a}$ & $20,23 \pm 3,79^{a b}$ \\
\hline Konversi ransum (KA 13\%) & $3,57 \pm 0,16^{b}$ & $2,68 \pm 0,58^{\mathrm{a}}$ & $2,61 \pm 0,52^{\mathrm{a}}$ & $3,10 \pm 0,21^{\mathrm{a}}$ \\
\hline
\end{tabular}

Superskrip yang berbeda pada kolom yang sama menunjukkan perbedaan nyata $(P<0,05)$

dengan probiotik (Daun et al. 2017) dan penggunaan 14\% keong mas dalam ransum yang difermentasi (Muhammad et al. 2014). Pemberian keong mas pada itik dan ayam mampu meningkatkan bobot badan dan produksi telur (Susanto 1993). Penggunaan sagu kukus dan tepung keong mas sebagai pengganti jagung kuning untuk sumber energi sampai $45 \%$ menghasilkan bobot badan, pertambahan bobot badan, konversi ransum yang lebih baik pada itik hasil persilangan dibanding kedua tetuanya (Subhan et al.2010)

\section{Organ Dalam Karkas Itik Persilangan Mojosari- Peking}

Persentase organ dalam hati itik Mojosari-Peking pada penelitian ini nyata $(\mathrm{p}<0,05)$ dipengaruhi oleh suplemen keong mas rebus pada ransum berbasis limbah restoran dan ampas kelapa adalah hati dan gizzard (Tabel 4). Persentase bobot hati menurun dengan suplemen keong mas rebus $10-20 \%$ dibandingkan kontrol. Hati merupakan organ yang berfungsi untuk melakukan detoksifikasi racun. Keong mas yang diambil dari lingkungan persawahan ada kemungkinan mengandung residu obat-obat kimia dari lingkungan keong mas hidup, walaupun keong yang digunakan pada penelitian ini sudah direbus selama 20 menit. Selain itu ada kemungkinan faktor lain yang ada di dalam keong mas yang seharusnya kerja hati untuk mendetoksifikasi rancun ternyata bobot hati lebih rendah daripada kontrol. Penurunan bobot hati diduga adanya senyawa yang menekan bobot hati. Hal ini tidak sesuai dengan penelitian Sumiati \& Sumirat (2003) yang mendapatkan persentase bobot hati sebesar 3,09\%.

Suplementasi keong mas rebus dalam ransum itik 10$20 \%$ menunjukkan bobot gizzard nyata lebih rendah $(\mathrm{p}<0,05)$ dibandingkan kontrol (Tabel 4). Keong mas yang diberikan bersama cangkangnya dan hanya dipecah dapat membantu proses pencernaan ransum di gizzard.

Tabel 4 Rataan bobot dan persentase organ dalam Itik Mojosari-Peking umur 63 hari

\begin{tabular}{lllll}
\hline \multirow{2}{*}{ Peubah } & \multicolumn{4}{c}{ Suplementasi Keong Mas Rebus (\%) } \\
\cline { 2 - 5 } & 0 & 10 & 15 & 20 \\
\hline Hati (g) & $31,06 \pm 4,85$ & $34,08 \pm 7,67$ & $32,23 \pm 2,88$ & $34,74 \pm 4,86$ \\
(\%) & $2,82 \pm 0,38^{\mathrm{a}}$ & $2,36 \pm 0,42^{\mathrm{b}}$ & $2,26 \pm 0,29^{\mathrm{b}}$ & $2,38 \pm 0,49^{\mathrm{b}}$ \\
Jantung (g) & $7,24 \pm 0,75$ & $9,57 \pm 1,87$ & $10,6 \pm 2,28$ & $10,26 \pm 2,07$ \\
(\%) & $0,66 \pm 0,59$ & $0,66 \pm 0,92$ & $0,74 \pm 0,20$ & $0,70 \pm 0,19$ \\
Limpa (g) & $3,00 \pm 0,82$ & $3,14 \pm 0,70$ & $3,59 \pm 0,61$ & $2,73 \pm 0,86$ \\
(\%) & $0,21 \pm 0,14$ & $0,22 \pm 0,040$ & $16 \pm 0,14$ & $0,14 \pm 0,09$ \\
Gizzard (g) & $44,96 \pm 4,30$ & $48,34 \pm 9,10$ & $49,39 \pm 9,17$ & $58,37 \pm 7,79$ \\
(\%) & $4,09 \pm 0,19^{\mathrm{a}}$ & $3,36 \pm 0,48^{\mathrm{b}}$ & $3,45 \pm 0,83^{\mathrm{b}}$ & $3,93 \pm 0,74^{\text {ab }}$ \\
\hline
\end{tabular}

Superskrip yang berbeda pada kolom yang sama menunjukkan perbedaan nyata $(\mathrm{P}<0,05)$.
Ransum itik yang terdiri dari limbah restoran dan ampas kelapa yang diberikan dalam bentuk basah sangat terbantu dengan adanya cangkang keong mas. Fungsi cangkang dapat sebagai grit di dalam gizzard yang membantu mencerna ransum sehingga memperingan kerja gizzard. Persentase gizzard pada itik lokal jantan umur 8 minggu sebesar 4,36\% (Sumiati \& Sumirat 2003).

Suplementasi keong mas dalam ransum tidak berpengaruh nyata terhadap persentase limpa dan jantung (Tabel 4). Kelainan limpa dan jantung tidak terlihat dari persentase bobotnya sehingga suplementasi keong mas tidak mengganggu kesehatan jantung dan limpa.

\section{Persentase Bobot Karkas dan Bobot Lemak Abdominal Itik Mojosari-Peking}

Suplemen keong mas rebus dalam ransum itik mempengaruhi $(\mathrm{p}<0,05)$ nilai rataan persentase bobot karkas dan bobot lemak abdominal (Tabel 5). Rataan bobot potong itik Mojosari-Peking masih lebih rendah dari itik peking dengan umur yang sama dengan pemberian ransum komersial yaitu sebesar 1602,5 gram ekor $^{-1}$ (Sukirmansyah et al. 2016). Persentase bobot karkas itik peking umur 8 minggu sebesar 55\% (Daud et al. 2016) dan persentase itik lokal jantan umur 8 minggu 56\% (Sumiati \& Sumirat, 2003). Ransum yang berbasis limbah restoran dan ampas kelapa belum dapat menyamai bobot potong itik Peking karena mengandung nutrien yang dibawah kebutuhan untuk pertumbuhan yang maksimal.

Suplementasi keong mas $15 \%$ pada ransum itik berbasis limbah restoran dan ampas kelapa menghasilkan persentase bobot karkas paling tinggi dibandingkan perlakuan lainnya (Tabel 5). Persentase bobot karkas hasil penelitian lebih tinggi dibandingkan persentase itik peking sebesar 52\% (Sukirmansyah et al. 2016). Persentase bobot karkas hasil penelitian ini jika dibandingkan dengan itik mojosari afkir lebih tinggi. Itik afkir Peking-Alabio dan Peking-Mojosari masing masing sebesar 54,25\% (Suparyanto 2006).

Suplementasi keong mas dalam ransum berbasis limbah restoran dan ampas kelapa menghasilkan lemak abdominal yang semakin menurun karena terjadi perubahan rasio energi-protein yang yang lebih seimbang (Tabel 5). Kelebihan energi atau protein yang tidak seimbang dapat menyebabkan meningkat atau menurunnya lemak abdominal. Lemak abdominal juga dipengaruhi oleh umur itik. Imbangan energi-protein 198-200 pada itik lokal jantan mempengaruhi persentase lemakabdominal (Dewanti etal. 2013). 
Tabel 5 Rataan persentase bobot karkas dan lemak abdominal

\begin{tabular}{|c|c|c|c|c|}
\hline \multirow{2}{*}{ Peubah } & \multicolumn{3}{|c|}{ Suplementasi Keong Mas Rebus (\%) } & \multirow[b]{2}{*}{20} \\
\hline & 0 & 10 & 15 & \\
\hline Bobot potong (g ekor ${ }^{-1}$ ) & $1099,06 \pm 62,50$ & $1432 \pm 96,31$ & $1458,06 \pm 155,01$ & $1501,3 \pm 79,6$ \\
\hline Bobot karkas (g ekor ${ }^{-1}$ ) & $607,9 \pm 42,90$ & $814,44 \pm 90,30$ & $945,13 \pm 46,30$ & $830,8 \pm 53,7$ \\
\hline Bobot karkas/bobot hidup (\%) & $55,29 \pm 1,15^{a}$ & $56,80 \pm 3,7^{\mathrm{a}}$ & $65,15 \pm 4,14^{b}$ & $55,42 \pm 3,95^{a}$ \\
\hline Lemak abdominal (g ekor ${ }^{-1}$ ) & $15,8 \pm 2,19$ & $18,43 \pm 4,48$ & $16,69 \pm 2,97$ & $14,68 \pm 1,07$ \\
\hline Lemak abdominal/bobot hidup (\%) & $2,61 \pm 0,37^{\mathrm{ab}}$ & $2,25 \pm 0,37^{\text {ab }}$ & $1,76 \pm 0,28^{b}$ & $1,75 \pm 0,06^{\mathrm{a}}$ \\
\hline
\end{tabular}

Superskrip huruf kecil yang berbeda pada baris yang sama menunjukan berbeda nyata $(p<0,05)$

\section{SIMPULAN}

Suplementasi keong mas rebus $15 \%$ pada ransum itik Mojosari-Peking berbasis limbah restoran dan ampas kelapa dengan perbandingan 1:2 menghasilkan performa yang lebih baik dibandingkan dengan ransum tanpa suplementasi keong mas rebus.

\section{DAFTAR PUSTAKA}

Bombeo-tuburan I, Fukumoto S \& Rodriquez E.1995. Use of the golden apple snail cassava and maize as feeds for the tiger shrimp, penaeus monodon, in ponds. Aquaculture 131(1-2) : 91-100

Budiari NLG, Adijaya IN \& Kertawirawan A. 2016. Pengaruh pemberian tepung keong mas terhadap pertumbuhan ternak entog. Prosiding Seminar Nasional Inovasi Teknologi Pertanian, Banjarbaru (ID): Balai Pengkajian Teknologi Pertanian Bali.

Daud M, Mulyadi \& Fuadi Z. 2016. Persentase karkas Itik Peking yang diber pakan dalam bentuk wafer ransum komplit mengandung limbah kopi. Jurnal Agripet 16(1) : 62-68.

Daun M, Yaman MA, Latif H \& Asril. 2017. Penggunaan tepung keong mas dan suplementasi probiotik dalam ransum terhadap performa itik peking. Prosiding Seminar Nasional Teknologi Peternakan dan Veteriner. Bogor (ID): Pusat Penelitian dan Pengembangan Peternakan.

Dewanti, R, Irham M \& Sudiyono. 2013. Pengaruh penggunaan eceng gondok (Eichhornia crassipes) terfermentasi dalam ransumk terhadap persentase karkas, non karkas, dcan lemak abdominal itik jantan umur delapan minggu. Buletin Peternakan. 37(1): 19-25.

Hertrampf, J W \& Piedad-Pascual F.2000. Handbook on Ingredient for Aquaculture Feeds. Kluwer Academic Publisher, London https://www.springer.com/gp/book/9780412627606

Jintasataporn, PT \& Yenmark S. 2004. Substitution of golden apple snail meal for fishmeal in giant freshwater prawn, Macrobrachium resenbergii (de man) Diets. Kasetsart Journal (Natural Science). 38 66-71

Kaensombath L. 2016. Evaluation of the nutritive value of ensiled and fresh golden apple snails (Pomaceae sp) for growing pig. http://www.researchgate.net/publication/267952175

Kurniawan LA, Atmomarsono U \& Mahfudz LD. 2012. Pengaruh berbagai frekuensi pemberian pakan dan pembatasan pakan terhadap pertumbuhan tulang ayam broiler. Agromedia 30(2):14-22.

Miskiyah, Mulyawati I \& Haliza W. 2006. Pemanfaatan ampas kelapa limbah pengolahan minyak kelapa murni menjadi pakan. Prosiding Seminar Nasional Teknologi Peternakan dan Veteriner, Balai Besar Penelitian dan Pengembangan Pascapanen Pertanian ID : Bogor

Muflihani Y, Zainuddin D, Suryawati RW \& Rochjat M. 2000. Pemanfaatan Limbah Restoran untuk Ransum Ayam Buras. Balai Penelitian dan Pengembangan Pertanian ID: Jakarta

Muhammad N, Sahara E, Sandi S \& Yosi F. 2014. Pemberian ransum komplit berbasis bahan baku lokal fermentasi terhadap konsumsi, pertambahan bobot badan dan berat telur itik lokal Sumatera Selatan. Jurnal Peternakan Sriwijaya 3(2): 20-27

Nafiu LO \& Pagala MA. 2010. Pemberian keong mas (Pomacea sp.) dalam pakan terhadap penampilan itik Bali dan itik Tegal. Agriplus 20(1): 36-41.

Ramdani I, Kardaya D \& Anggraeni. 2016. Pengaruh subsitusi pakan komersil dengan tepung ampas kelapa terhadap bobot potong dan bobot karkas ayam kampung. Jurnal Peternakan Nusantara 2(1): 9-16.
Subhan, A. 2016. Populasi dan potensi keong mas (Pomaceae canalicuta) sebagai sumber bahan pakan itik alabio (Anas plathyrinchos Borneo) di Kalimantan Selatan. Prosiding Seminar Nasional Inovasi Teknologi Pertanian. Banjarbaru (ID) : Balai Pengkajian Teknologi Pertanian Bali.

Subhan A, Yuwanta, T \& Sidadolog, JHP. 2010. Pengaruh kombinasi sagu kukus (Metroxylon spp) dan tepung keong mas (Pomacea spp) sebagai pengganti jagung kuning terhadap penampilan itik jantan alabio, mojosari, dan hasil persilangannya. Buletin Peternakan 34 (1) : 30-37

Sukirmansyah, Daud M \& Latif H.2016. Evaluasi produksi dan persentase karkas Itik peking dengan pemberian pakan fermentasi probiotik. JIMFP. 1(1): 719-730.

Sumiati \& Sumirat A. 2003. Persentase bobot saluran pencernaan dan organ dalam itik lokal jantan (Anas plathyrncos) jantan yang diberi berbagai taraf kayambang (Salvinia molesta) dalam ransum. Media Peternakan. 26(1): 11-16.

Sundari. 2004. Evaluasi energi metabolis tepung keong mas (Pomacea sp) pada itik lokal jantan. Buletin Pertanian dan Peternakan. 5(10): 115-123.

Suparyanto A. 2006. Karakteristik ukuran karkas itik genotipe peking x alabio dan peking $\mathrm{x}$ mojosari. Prosiding Lokakarya Nasional Inovasi Teknologi dalam Mendukung Usaha ternak Unggas Berdayasaing, Bogor (ID) : Pusat Penelitian dan Pengembangan Peternakan. 